\title{
Niedoceniana ścieżka emancypacji: żenujący kobiecy performans
}

Katarzyna Waligóra

TEKSTY DRUGIE 2020, NR 6, S. 157-178

DOI: 10.18318/td.2020.6.10 | ORCID: 0000-0001-5297-2889

$\mathbf{K}$ iedy 28 października 1989 roku w wywiadzie udzielonym prezenterce „Dziennika Telewizyjnego” Joanna Szczepkowska wypowiedziała słynne zdanie: „Proszę państwa, 4 czerwca 89 roku skończył się w Polsce komunizm", niewielu dostrzegło w nim przejaw kobiecej emancypacji. Szczepkowska mówiła przecież jako trochę szalona i niepoważna, ale jednak Polka i patriotka. Kiedy 3 kwietnia 2016 roku Anka Zet Zawadzka przerwała w kościele św. Anny w Warszawie czytanie listu biskupów nawołującego do zaostrzenia ustawy aborcyjnej, sprawa trafiła do prokuratury, a zachowanie kobiety wielu uznało za świętokradcze. Za przesadę, ekshibicjonizm i szaleństwo dość powszechnie uznawano też publiczne oświadczenie Katarzyny Bratkowskiej, że przerwie ciążę w Wigilię 2013 roku. A kiedy w 2007 roku Manuela Gretkowska założyła Partię Kobiet, mało kto wierzył, że ta inicjatywa, wdzięczny obiekt żartów znanych publicystów, może zakończyć się sukcesem. Wyśmiewano Joannę Muchę za to, że poprosiła, by tytułowano ją ministrą,
Katarzyna Waligóra

- doktorantka

w Katedrze Teatru

i Dramatu Uniwersy-

tetu Jagiellońskiego.

Stale współpracuje

z pismem „Didaska-

lia."Interesuje się

wystąpieniami kobiet w sferze publicznej, materialnością teatru oraz przyczynami porażek spektakli teatralnych. Autorka książki „Koń nie jest nowy."O rekwizytach w teatrze. 
a nie ministrem, oraz Annę Grodzką za bycie pierwszą transseksualną parlamentarzystką. Między tymi kobiecymi ingerencjami w sferę publiczną, choć charakteryzuje je różna forma, stopień podejmowanego ryzyka czy skala oddziaływania, można znaleźć wiele podobieństw. W niniejszym artykule chciałabym zarysować teoretyczne podstawy opisu grupy tego typu emancypacyjnych, jednostkowych praktyk: żałosnych, głupich, słabych, atakowanych, wyśmiewanych, nierozumianych, odrzuconych. Uważam, że warto poświęcić im uwagę, bo mają ogromny potencjał skutecznego przekształcania sfery publicznej i politycznej. Określam je mianem żenujących kobiecych performansów.

Sformułowanie to zapożyczam (choć nie w dokładnym brzemieniu) $\mathrm{z}$ artykułu Marcina Kościelniaka Żenujące performanse przegranych. Przeciw-historie teatru zaangażowanego ${ }^{1}$. Kościelniak w swoim tekście pisze o żenujących performansach przegranych, czyli takich scenach w obrębie spektakli teatralnych, w których wypowiedzi są formułowane z pozycji słabej i nieporadnej. Wspomina na przykład o monologach pojawiających się w spektaklach Strzępki i Demirskiego:

Chcę zwrócić uwagę na szczególny tryb, w jakim prowadzone są te monologi. Nie odwołują się one do rzeczowej, celnej argumentacji, nie sięgają po inteligentną ripostę, nie próbują przekonać obrazoburczą retoryką, przeciwnie: zazwyczaj monologi są nieskładne, bełkotliwe, łzawe czy też po prostu nieudane. [...] U Strzępki i Demirskiego w żenujących performansach przegranych to właśnie szczerość, emocjonalność i nieudolność są orężem walki z zakłamaną, cyniczną i skuteczną retoryką zwycięzców. ${ }^{2}$

Analizując częściowo improwizowany monolog Justyny Wasilewskiej w Balladynie Krzysztofa Garbaczewskiego i Marcina Cecki, dodaje:

Grany za każdym razem wedle zmienionych i na bieżąco ustalanych reguł perfomans nie jest dobrze naoliwioną maszyną, przeciwnie: bywa zagmatwany i bełkotliwy, a Wasilewska - takie jest pierwsze wrażenie - jest gotowa lada moment zaciąć się, skapitulować, skompromitować.

1 Por. M. Kościelniak Żenujące performanse przegranych. Przeciw-historie teatru zaangażowanego, "Didaskalia” $2013 \mathrm{nr}$ 115/116.

2 Tamże, s. 75-76. 
To sprawia, że jej żenujący performans jest niezwykle skuteczny, a przy tym przejmujący. ${ }^{3}$

Żenujący performans jest dla Kościelniaka indywidualnym aktorskim wystąpieniem w obrębie spektaklu bazującym na porozumieniu między wykonawcą lub wykonawczynią a widzami. Ważna jest w nim nie tyle dyskursywna spójność, ile afektywna siła rażenia. Żenujący performans jest przy tym wykonywany przez podmiot, który obnaża swoją słabość, bezsilność i porażkowość (i na tym polu buduje wspomniane empatyczne porozumienie $\mathrm{z}$ widzem).

Kategorię zaproponowaną przez Marcina Kościelniaka uważam za bardzo interesującą, ale chciałabym ją zreinterpretować na użytek własnych badań. Przedmiotem moich zainteresowań są bowiem wybrane działania podejmowane przez kobiety w polskiej sferze publicznej od roku 1989 do dziś. Najstarszy żenujący performans, który potrafię zidentyfikować, to wspomniane ogłoszenie końca komunizmu w „Dzienniku Telewizyjnym”, ostatni omawiany miał miejsce w lutym 2018 roku, kiedy ukazał się numer „Wysokich Obcasów" ze zdjęciem przedstawicielek grupy Aborcyjny Dream Team na okładce. Pragnę podkreślić, że wbrew językowym zwyczajom słowo „żenujący" nie ma w moim ujęciu zabarwienia negatywnego. Żenada jest w moich badaniach neutralnym i adekwatnym określeniem techniki stosowanej przez kobiety w celu wypowiedzenia określonych racji, których w innych okolicznościach nikt nie chciałby słuchać. Zamierzam przechwycić to słowo, tak żeby straciło ono swój piętnujący, deprecjonujący czy ośmieszający charakter i stało się nazwą jednej ze strategii pojawiania się w przestrzeni publicznej. Każdy żenujący kobiecy performans można opisać za pomocą pięciu podstawowych elementów, które chciałabym teraz kolejno omówić.

\section{Po pierwsze: żenujący kobiecy performans rozgrywa się w przestrzeni publicznej}

Pisząc o żenujących performansach przegranych, Marcin Kościelniak odwoływał się do scen, które rozgrywają się jako zaplanowana część spektaklu teatralnego. Nawet jeśli miały one charakter (zwykle częściowej) improwizacji, to improwizowanie odbywało się w pewnej ramie tematycznej ustalonej przez aktora wspólnie z reżyserem i dramaturgiem (lub przez nich narzuconej). Joanna Jopek w artykule Praktyka porażki. Próby performatywności negatywnej

3 Tamże, s. 79. 
analizowała z kolei działania polskich artystów sztuk wizualnych oparte na podobnym wzorcu posługiwania się słabym, porażkowym, często żenującym dyskursem ${ }^{4}$. Badaczka przywoływała działania Oskara Dawickiego i Joanny Rajkowskiej, choć można byłoby do nich dołączyć wielu innych artystów, choćby Katarzynę Kozyrę, grupę Virgin\$ deLuxe Edition czy grupę Sędzia Główny. Artyści ci jednak wytyczają granicę między swoją sztuką a życiem prywatnym, żenadę uznają przede wszystkim za temat wart analizy, a efekty ich działań są produktami na rynku sztuki.

Określenie „żenujący kobiecy performans” może też przywodzić na myśl sztukę żenującą, czyli projekt artystyczny prowadzony w latach 1980-1989 przez związanego z Kulturą Zrzuty artystę i performera Marka Janiaka, powracający także w pracach innych artystów (projekt był szczególnie istotny dla Zbigniewa Libery). Ramę teoretyczną sztuki żenującej wyznaczały cztery manifesty Janiaka powstałe w latach 1980-1984 $4^{5}$. Zwłaszcza w pierwszym z nich można znaleźć idee brzmiące podobne do tych, które przedstawię w niniejszym tekście jako charakterystyczne dla żenującego kobiecego performansu. Są to: ujawnienie prywatnej emocjonalności, zwrócenie się przeciwko normom kulturowym, indywidualność gestu, wywoływanie zażenowania6. Pisząc o sztuce żenującej, Janiak miał jednak na myśli działania artystyczne wyraźnie włączone w porządek sztuki, choć oddziałujące też w sferze społeczno-politycznej. Przedstawiając je w swoim manifeście przy użyciu zestawu pojęć, posłużył się określeniami bardzo odmiennymi od tych, za pomocą których możemy opisywać żenujący kobiecy performans, na przykład: trywialny, nieciekawy, nieodkrywczy, nijaki, bezmyślny. Przykładem realizacji sztuki żenującej są Ćwiczenia dokamerowe, które Filmoteka Muzeum Sztuki Nowoczesnej w Warszawie opisuje jako rejestrację: „krótkich działań dokamerowych polegających na bezsensownych zmaganiach, często wykraczających poza możliwości ludzkiego ciała i wykorzystywanej materii"'. Sztuka żenująca w zamierzeniu Janiaka miała być gestem obronnym artysty przeciwko społecznej

4 Por. J. Jopek Praktyka porażki. Próby performatywności negatywnej, „Didaskalia” 2013 nr 115/116.

5 Por. M. Kościelniak Egoiści. Trzecia droga w kulturze polskiej lat 8o., Instytut Teatralny im. Zbigniewa Raszewskiego, Warszawa 2018, s. 311.

6 Por. M. Janiak Sztuka żenująca (sztuka która żenuje zażenowanie jako sztuka), Łódź 22.10.1980, internetowe archiwum Kultury Zrzuty, http://www.kulturazrzuty.pl/tworcy-janiak.php (dostęp: 11.01.2020).

7 M. Janiak Ćwiczenia wyzwalajq̨ce, Filmoteka Muzeum Sztuki Nowoczesnej w Warszawie, https:// artmuseum.pl/pl/filmoteka/praca/janiak-marek-cwiczenia-wyzwalajace (dostęp: 11.01.2020). 
opresji. Jak jednak zauważa Marcin Kościelniak w niedawno wydanej obszernej pracy na temat Kultury Zrzuty, środowisko to dalekie było od praktykowania idei feministycznych:

Monkiewicz podkreśla, że środowisko Kultury Zrzuty było wspólnotą młodych mężczyzn, w której kobiety najczęściej odgrywały narzucone role. [...] Rzecz widać najlepiej na gruncie przywoływanych wcześniej statystyk dotyczących obecności kobiet w środowisku i widoczności ich prac w środowiskach medialnych. Widać to także w samych, nielicznych, pracach kobiet. $^{\mathbf{8}}$

Kościelniak pisze wprost:

Jeżeli zatem środowisko Kultury Zrzuty konstytuowała problematyka konstruktywizmu społecznego w perspektywie kultury narodowo-katolickiej, o tyle nie został przez środowisko podważony stanowiący rdzeń tej kultury porządek patriarchalnych norm. Fakt ten ustanawia płaszczyznę nieoczekiwanego sojuszu pomiędzy kulturą narodową a Kulturą Zrzuty: w obydwu przypadkach „wybitnie męską". Gwarantem tego sojuszu jest sięgająca trzewi polskiej kultury wybitnie męska dominacja, przekraczająca najgłębsze społeczne, polityczne i artystyczne podziały. ${ }^{9}$

Sztuka żenująca, nawet jeśli jest działaniem słabym i porażkowym, to podejmowanym przez mocny podmiot, jakim jest mężczyzna-artysta. Zarówno w formie, jak i w temacie w istocie bardzo różni się więc od tego, co określam jako żenujący kobiecy performans.

Żenujące kobiece performanse, które mnie interesują, są zasadniczo odmienne od tych, które przywołują Kościelniak czy Jopek. Przede wszystkim nie mają charakteru happeningu czy prowokacji artystycznej - ani przez widzów, ani przez same performerki nie są opisywane jako działania artystyczne. Żenujący kobiecy performans, nawet jeśli rozgrywa się w teatrze, jak performans Joanny Szczepkowskiej na premierze Persony. Ciała Simone ${ }^{\mathbf{1 0}}$,

8 M. KościelniakEgoiści, s. 433.

9 Tamże, s. 439.

10 W czasie premiery spektaklu Persona. Ciało Simone Joanna Szczepkowska, na znak protestu przeciwko praktykom reżyserskim Krystiana Lupy, jak później tłumaczyła, wykonała trzy nieustalone wcześniej gesty, spośród których najbardziej komentowane było pokazanie nagich 
nie odbywa się w ramie teatralnego czy galeryjnego spektaklu; nigdy nie jest też przez nikogo reżyserowany. Tak naprawdę prawie nigdy nie posługuje się nawet artystycznymi technikami, korzysta raczej z form publicystycznych (felieton, konferencja prasowa, wywiad) lub aktywistycznych (demonstracja, założenie partii politycznej), które traktuje serio. Żenująca performerka, nawet jeśli jest artystką, w czasie dokonywania żenującego performansu nie jest postrzegana jako artystka, zawsze występuje pod swoim nazwiskiem, wykorzystuje swój publiczny status i wizerunek, a za przeprowadzone działanie ponosi osobistą odpowiedzialność i zwykle płaci wysoką cenę. Jednak tak samo jak performerka ochrony ze strony konwencji teatralnej iluzji są pozbawieni odbiorcy, którzy na innych niż w teatrze zasadach muszą skonfrontować się z doświadczanymi emocjami.

Sceną żenującego kobiecego performansu jest więc sfera publiczna, a jego celem - wywarcie wpływu na rzeczywistość społeczno-polityczną, ale także nadanie swojemu głosowi siły oddziaływania. Nancy Fraser w artykule Rethinking the Public Sphere: A Contribution to the Critique of Actually Existing Democracy podejmuje refleksję nad koncepcją sfery publicznej zaproponowaną przez Jürgena Habermasa i określa ją jako:

teatr zaprojektowany w nowoczesnym społeczeństwie, w którym partycypacja polityczna przejawia się poprzez medium rozmowy. To przestrzeń, w której obywatele rozważają swoje codzienne sprawy, a więc zinstytucjonalizowany obszar dyskursywnych interakcji."

Sfera publiczna jest oddzielona od władzy państwowej (dzięki czemu może pozostawać wobec niej krytyczna) oraz od sfery ekonomicznej (to przestrzeń rozmowy, a nie kupna i sprzedaży).Zdaniem Fraser koncepcja Habermasa pozwala wprowadzić niezbędne dla współczesnej demokracji rozróżnienie aparatu państwowego, rynku i instytucji demokratycznych ${ }^{12}$. Badaczka zaznacza jednak, że choć teoretyczna idea sfery publicznej wydaje

pośladków. Protest aktorki wywołał w środowisku teatralnym i medialnym ogromną dyskusję, w czasie której Szczepkowska przeważnie była krytykowana i potępiana. Za wydarzenie na premierze została przez Lupę wyrzucona z obsady spektaklu i zastąpiona przez Maję Ostaszewską.

11 N. Fraser Rethinking the Public Sphere: A Contribution to the Critique of Actually Existing Democracy , "Social Text" 1990 no. 25/26, s. 57. 
jej się niezbędna do myślenia o współczesności, to szczegółowe propozycje Habermasa nie są już dla niej w pełni satysfakcjonujące. Fraser przedstawia cztery punkty, w których koncepcja niemieckiego filozofa wymaga rewizji. Po pierwsze, założenie, że debatujący w sferze publicznej mogą działać, jak gdyby posiadali równy status społeczny (bez faktycznego równouprawnienia). Po drugie, stwierdzenie, że wielość publiczności jest raczej krokiem wstecz niż w kierunku większej demokratyzacji i że jedna racjonalna sfera publiczna zawsze jest lepsza niż wiele sfer tego rodzaju. Po trzecie, założenie, że rozmowy prowadzone w sferze publicznej powinny ograniczać się do tego, co jest dobrem wspólnym, i że pojawienie się w niej prywatnych interesów zawsze jest niepożądane. I po czwarte, teza, że sprawnie funkcjonująca sfera publiczna wymaga ostrego rozdzielenia państwa od społeczeństwa obywatelskiego ${ }^{13}$.

Z mojego punktu widzenia w artykule Fraser najważniejsza w tym momencie jest obserwacja, że męska i burżuazyjna sfera publiczna w rozumieniu Habermasa tylko teoretycznie zakładała, że możliwe jest wzięcie w nawias społecznych różnic i umożliwienie dyskutantom rozmowy, jak gdyby te różnice nie istniały. Sfera publiczna miała być inkluzywna i dostępna, choć oczywiście to założenie nigdy nie zostało zrealizowane ze względu na istniejące wówczas formalne wykluczenia genderowe i klasowe, a w wielu społeczeństwach także rasowe. Badaczka zauważa, że we współczesnej demokracji, choć formalne bariery zostały zniesione, sfera publiczna wcale nie stała się dzięki temu w pełni dostępna i inkluzywna, co widać przy bliższym przyjrzeniu się praktykom dyskursywnym zachodzącym w jej ramach. Nie wszystkie bowiem bariery mają naturę formalną, część wynika z umownych zasad, manier i konwenansów. Fraser przywołuje feministyczne obserwacje, z których wynika, że mężczyźni częściej niż kobiety zabierają głos w dyskusjach, częściej przerywają kobietom i często ignorują ich opinie. Podobnych wykluczeń doświadczają także inne grupy. Zadaniem teorii krytycznej jest więc, zdaniem Fraser, ujawnienie społecznych nierówności, które działają w obrębie oficjalnie równościowych sfer publicznych i wpływają na kształt zachodzących w nich interakcji. Nierówności te mają następnie zostać przezwyciężone, a nie tylko pominięte. Podobne funkcje spełnia żenujący performans.

Jeśli przyjrzymy się polskiej sferze publicznej, nie znajdziemy oczywiście formalnych przeciwwskazań do zabierania przez kobiety głosu. Kiedy jednak zaczynamy obserwować sytuację kobiet w polskim społeczeństwie, dostrzegamy szereg czynników, które utrudniają im wejście w przestrzeń

Por. tamże, s. 62-63. 
debaty albo sprawne w niej funkcjonowanie. Wśród nich cztery są moim zdaniem szczególnie istotne. Po pierwsze, kobiety mają prawo stale czuć się zagrożone, bo znacznie częściej niż mężczyźni padają ofiarami przemocy fizycznej i seksualnej - co roku od siedmiuset tysięcy do miliona Polek doświadcza przemocy i co roku sto pięćdziesiąt kobiet ginie wskutek przemocy domowej. Sprawcy przemocy bardzo rzadko zostają skazani na karę więzienia (zwykle albo unikają kary albo otrzymują wyroki w zawieszeniu) ${ }^{14}$. Po drugie, kobiety muszą poświęcić więcej energii na zapewnienie sobie stabilizacji ekonomicznej. Według danych Głównego Urzędu Statystycznego Polki zarabiają średnio o 18,5 procenta mniej niż mężczyźni (około siedmiuset złotych brutto miesięcznie), choć częściej niż oni są dobrze wykształcone ${ }^{15}$.Zgodnie z obowiązującym prawem wcześniej przechodzą też na emeryturę i z tego powodu otrzymują znacznie niższe świadczenia, a w wielu zawodach mają utrudnioną ścieżkę kariery. Po trzecie, kobiety mają znacząco mniejszy udział w życiu politycznym. Dotyczy to oczywiście w pewnym stopniu reprezentacji ilościowej - najwięcej, a i tak zaledwie 28 procent wszystkich mandatów w parlamencie, udało się kobietom zdobyć w ostatnich wyborach, co przekłada się na stutrzydziestojednoosobową reprezentację (na czterysta sześćdziesiąt miejsc). Przede wszystkim chodzi mi jednak o słabą reprezentację w sferze politycznej kobiecych problemów, takich jak: dostęp do godnej opieki ginekologicznej, przemoc domowa i sposoby jej przeciwdziałania, wsparcie dla matek, zwłaszcza tych samotnie wychowujących dziecko, ochrona homoseksualnych i transsekuslanych kobiet przed przemocą i nienawiścią czy sytuacja kobiet na rynku pracy. Wreszcie, po czwarte, obowiązująca od 1993 roku ustawa niemal całkowicie zakazująca lekarzom przeprowadzania aborcji uniemożliwia kobietom podejmowanie decyzji o własnym ciele i jest narzędziem sprawowania opresyjnej kontroli. Obecne prawo limitujące zabiegi przerywania ciąży wpływa też na dostępność innych, niezwiązanych z aborcją świadczeń medycznych (przede wszystkim badań prenatalnych). Kobiety przerywające ciążę są stygmatyzowane, więc decyzja o aborcji jest często podejmowana w tajemnicy, pociąga za sobą poczucie winy i wstydu. Wszystkie

Por. Nawet milion Polek doświadcza co roku przemocy fizycznej lub seksualnej, "Gazeta Wyborcza" 22.09.2014, http://wyborcza.pl/1,75398,16687214,Nawet_milion_Polek_kazdego_roku_ doswiadcza_przemocy.html (dostęp: 5.07.2019).

15 Por. Ponad 700 zł. O tyle więcej średnio zarabia Polak w porównaniu z Polkq , "Forbes" 12.09.2018, https://www.forbes.pl/finanse/zarobki-kobiet-i-mezczyzn-w-polsce-gender-pay-gap-wpolsce-dane-gus/thtq1yw (dostęp: 5.07.2019). 
te czynniki nie tylko prowadzą do bezpośredniego wyłączenia kobiet ze sfery publicznej, ale także modelują dyskurs na ich temat. Patriarchat rozumiem właśnie jako takie nierówne ukształtowanie sfery publicznej, które prowadzi do genderowych wykluczeń. Jednym ze skutków żenujących kobiecych performansów jest natomiast ujawnienie obszarów jego działania i stosowanych przez niego technik. W tym sensie żenujący kobiecy performans ma charakter feministyczny, nawet jeśli wykonująca go performerka nie należy do żadnych organizacji kobiecych ani nie uznaje siebie samej za feministkę.

\section{Po drugie: żenujący kobiecy performans wzbudza zażenowanie}

Ta tautologiczna z pozoru zasada jest ważna, bo określa kierunek cyrkulacji afektów. Jak zauważa Luke Purshouse w artykule Embarrassment:A PhilosophicalAnalysis, uczucie zażenowania może występować pod dwiema postaciami: podmiot może je odczuwać wskutek znalezienia się w niezręcznej sytuacji (na przykład kiedy popełnia błąd w interakcji towarzyskiej) albo gdy jest świadkiem niestosownego zachowania kogoś innego, nawet jeśli nie ma na nie wpływu ${ }^{16}$. Purshouse dąży do stworzenia uniwersalnej definicji zażenowania, na tyle pojemnej, żeby objąć bardzo różne sytuacje, w których ludzie go doświadczają. Rozważa więc zarówno zdarzenia, w czasie których podmiot odczuwa zażenowanie, choć pozostali uczestnicy interakcji go nie doświadczają (na przykład podczas publicznego odbierania nagrody), oraz takie, gdy zażenowanie odczuwane jest niejako w imieniu kogoś innego, kto wcale go nie doświadcza (na przykład w sytuacji, kiedy pijany gość zaczyna przy kolacji mówić zbyt dużo i zbyt głośno). Dla żenującego kobiecego performansu kluczowy jest ten drugi przypadek. Żenująca performerka w czasie wystąpienia nie musi czuć się zażenowana. Może oczywiście odczuwać dyskomfort, bo przekracza społeczne konwencje i być może przewiduje negatywne reakcje obserwatorów, ale mimo to kontynuuje swoje działanie. Zwykle dlatego, że jest przekonana o ich słuszności i znaczeniu.

Purshouse w swoich rozważaniach uwzględnia zatem sytuację świadka, który czuje się zażenowany, tylko oglądając określoną sytuację. Analizując, skąd pojawia się to uczucie, badacz stwierdza, że dotychczasowe wyjaśnienia, proponowane przede wszystkim przez Gabrielle Taylor, są zbyt wąskie. Taylor tłumaczy pojawienie się afektu żenady albo empatyzowaniem, albo identyfikacją zażenowanego podmiotu z osobą, która jest źródłem niekomfortowej

16 Por. L. Purshouse Embarrassment: A Philosophical Analysis, „Philosophy” 2001 vol. 76 no. 298. 
sytuacji. Zdaniem Purshouse'a oba te wyjaśnienia, choć niekiedy mogą być trafne, nie stosują się do wszystkich przypadków17. Rozważenie szerokiego spektrum sytuacji prowadzi badacza do sformułowania własnej definicji, która skupia się nie tyle na samym afekcie, ile na sytuacji, w której zażenowanie się pojawia:

Moim zdaniem w zażenowaniu chodzi głównie o odsłonięcie jednej osoby przed drugą. Do interpersonalnego odsłonięcia dochodzi, kiedy jakiś aspekt jednej osoby (określam ją mianem eksponowanego) wkracza w sferę doświadczeń lub myśli innej osoby (którą określam jako adresata). Cechy eksponowanego, które mogą zostać odsłonięte, obejmują jego ciało, stan psychiczny, charakter i działania. Odsłonięcie zachodzi także wtedy, kiedy ktoś zdobywa wiedzę na temat kogoś innego. ${ }^{18}$

Zażenowanie może odczuwać albo eksponowany, albo adresat, albo obaj jednocześnie. Czasem nie jest też jasne, kto jest eksponowanym, a kto adresatem. Purshouse uzupełnia swoją definicję o stwierdzenie, że zażenowanie zawsze jest afektem negatywnym, który wyklucza równoczesne zaistnienie pozytywnych emocji, ale nie wyklucza współdziałania z innymi afektami negatywnymi. Co więcej: „Żeby dało się stwierdzić zażenowanie, podmiot musi nie tylko widzieć siebie jako uczestnika odsłonięcia, ale też być temu w jakiś sposób niechętny"19.

W przypadku żenującego kobiecego performansu dochodzi oczywiście do obscenicznego odsłonięcia - wykonawczyni wystawia na widok publiczny działania, które łamią zasady stosowności. Dodatkowo żenującego performansu nie da się przeprowadzić bez zaangażowania swojego wizerunku, a zwykle także bez odsłonięcia jakiejś części własnej, dotychczas strzeżonej prywatności (może to dotyczyć ciała, relacji rodzinnych, emocji, stanów psychicznych i tak dalej). Jak piszą Joanna Krakowska i Krystyna Duniec w książce Soc, sex i historia:

Już sam fakt zabrania głosu bywa obsceniczny. [...] Zabranie głosu po raz pierwszy jest obsceniczne szczególnie wtedy, kiedy jest przekroczeniem

Por. tamże, s. 527.

Tamże, s. 530-531. 
wstydu, wyrwaniem się z niewidzialności, przekroczeniem paktu milczenia. Nieprzyzwoite jest zabieranie głosu we własnej sprawie i imperatyw, by uczynić ją wspólną. Nieobyczajne jest wystawienie się na widok publiczny i mówienie „ja”; mówienie: „to moje doświadczenie”; mówienie: „to moje ciało, którego nie dam skolonizować, poddając się opresji cudzego spojrzenia i cudzej oceny. ${ }^{20}$

Purshouse duży udział w powstawaniu uczucia zażenowania przypisuje wykonaniu przez podmiot działań sprzecznych z etykietą, którą rozumie jako zestaw konwencjonalnych zasad regulujących życie społeczne przez podpowiadanie, co robić, mówić i jak wyglądać w określonej sytuacji ${ }^{21}$. W badaczu istnienie etykiety nie budzi podejrzeń i nie zajmuje się on analizowaniem jej dyscyplinującego wymiaru. Tymczasem etykieta nie tylko podpowiada - jak chce tego Purshouse - że nie należy zakładać stroju kąpielowego, gdy idzie się na konferencję naukową, ale może też ustalać, czego nie powinno się na tej konferencji prezentować albo jakich pytań nie powinno się stawiać. Nancy Fraser pisała, że nawet po zniesieniu formalnych barier dostęp do sfery publicznej regulowany jest przez umowne zasady, maniery i konwenanse te znowu są często bardzo bliskie etykiecie.

W myśleniu Purshouse'a zażenowanie jest jednak zawsze czymś, co się przydarza - nigdy nie jest wynikiem działania celowego. Tymczasem żenujące kobiece performanse można wstępnie podzielić na dwa typy. Pierwszy to takie wystąpienia, w których porażkowa, żenująca forma jest stosowana celowo i z pełnym przekonaniem o jej trafności. To często wystąpienia na pograniczu kpiny, groteskowej prowokacji lub błazenady. Taki charakter będą miały zarówno performans Joanny Szczepkowskiej na premierze spektaklu Persona. Ciało Simone, jak i publiczne oświadczenie Katarzyny Bratkowskiej, że zamierza dokonać aborcji w Wigilię. Drugi typ to wystąpienia, które mogą mieć formę zarówno żartobliwą (jak ogłoszenie końca komunizmu przez Joannę Szczepkowską), jak i w pełni poważną i oficjalną (jak założenie Partii Kobiet przez Manuelę Gretkowską). O tym, że możemy uznać je za żenujące performanse, decydują albo niezwykłe okoliczności, które im towarzyszą i naruszają powagę samego aktu, albo sposób, w jaki są postrzegane przez odbiorców. Oznacza to, że w innym kontekście społeczno-kulturowym performanse

\footnotetext{
20 J. Krakowska, K. Duniec Soc, sex i historia, Wydawnictwo Krytyki Politycznej, Warszawa 2014, s. 205. 
te mogłyby nie zostać odczytane jako żenujące. Znaczy to jednak także, że nie każdy widz jest adresatem, a żenujący kobiecy performans można odbierać na przynajmniej dwa sposoby: można podzielać uczucie zażenowania albo tylko obserwować zażenowanie $u$ innych. Zażenowanie w przypadku tego typu wystąpień działa też o tyle nietypowo, że choć zwykle łączy się z afektami negatywnymi, może łączyć się także z afektami pozytywnymi (głównie radością, ekscytacją, wzruszeniem), jeśli odbiorca (lub częściej odbiorczyni) podziela przekonania, w imię których występuje performerka.

\section{Po trzecie: żenujący kobiecy performans jest wykonywany ze słabej pozycji, ale nie produkuje słabego dyskursu}

W odróżnieniu od Luke'a Purshouse'a Martha Nussbaum wspomina o możliwości intencjonalnego wywołania zażenowania. Badaczka opisuje je w odniesieniu do dwóch innych, pokrewnych afektów: wstydu i upokorzenia. Uznaje przy tym, że zażenowanie w interakcjach społecznych występuje bardzo często, ale zwykle jest chwilowe, łatwo przemija i nie pozostawia śladu na psychice podmiotu. Afekt ten wywoływany jest przypadkowo, bo kiedy dochodzi do celowego zawstydzenia drugiej osoby, to zdaniem Nussbaum nie mówimy już o zażenowaniu, lecz raczej o upokorzeniu².

Analiza żenujących kobiecych performansów sprawia, że zdecydowanie nie zgadzam się z twierdzeniami Nussbaum, bo ten typ wystąpień dowodzi, że intencjonalne wywołanie zmieszania nie musi być tożsame z upokarzaniem kogokolwiek. Żenujący performans nie jest też samoupokorzeniem. Celowe zawstydzanie drugiego człowieka jest działaniem przemocowym, zwykle prowadzonym z pozycji siły. Tymczasem żenujący kobiecy performans zawsze jest wykonywany z pozycji słabości, przez osobę, która nie posiada dużej władzy w sprawie, w imię której występuje. W tym sensie jest on narzędziem wywrotowym i rewolucyjnym.

Żenujący kobiecy performans jest bronią słabych i marginalizowanych, która ze względu na to, że zawsze ściąga na performerkę bardzo negatywne reakcje (falę ocen, krytyki, pouczeń, obraźliwych komentarzy, inwektyw), jest zwykle bronią używaną w ostateczności. Jego wykonanie poprzedza zazwyczaj długotrwałe emocjonalne wzburzenie: frustracja, irytacja, niezadowolenie, niezgoda na zaistniałą sytuację, poczucie bezradności i tak dalej. Źródła

22 Por. M. Nussbaum Hiding from Humanity. Disgust, Shame and the Law, Princeton University Press, New Jersey 2004, s. 205-206. 
żenującego kobiecego performansu są więc bardzo podobne do źródeł tego, co Sara Ahmed w swoich książkach określa jako załamanie nerwowe (snap). W wykładzie Snap! Feminist Moments, Feminist Movements Ahmed pisze:

Jako czarna kobieta mówiąca o czarnych kobietach Faith ${ }^{23}$ musi krzyczeć, żeby zostać usłyszaną. Jeśli musisz krzyczeć, żeby zostać usłyszaną, nie jesteś słyszalna. Pomyśl o tym, jak wszystkie jej wysiłki, żeby zostać usłyszaną, żeby przebić się przez mur milczenia, mur obojętności zbudowany przez białych, spełzają na niczym. Pomyśl o tym, jak cała jej frustracja, wściekłość może stać się punktem zwrotnym. Tylko wtedy, kiedy wydajesz się przegrywać, kiedy krzyczysz, klniesz, wyrzucasz z siebie złość, zwracają na ciebie uwagę. I wtedy stajesz się spektaklem. A to, co z siebie wyrzuciłaś, oznacza, że musisz odejść. Kiedy myślimy o takich momentach załamania nerwowego (moments of snap), o tych momentach, kiedy już nie możesz tego wytrzymać, po prostu nie możesz wytrzymać, myślimy o zasadach działania świata. O tym, jak świat jest zorganizowany, żeby dawać powietrze jednym, utrudniając oddychanie innym. Musisz odejść, bo nic innego ci nie pozostało. ${ }^{24}$

Słowo snap używane przez Ahmed (i szerzej objaśnione przez nią w książce Living a Feminist Life) jest bardzo trudne do oddania w języku polskim, bo w oryginale może oznaczać zarówno załamanie nerwowe, jak i złamanie, pęknięcie (na przykład gałęzi). Badaczka używa obu wymiarów znaczeniowych, a to, co opisuje, to stan emocjonalnego wzburzenia, który popycha do działań niemożliwych do podjęcia w innej sytuacji. Z pozoru pojawia się nagle, ale, jak pisze Ahmed, ,to tylko jeden moment z długiej historii bycia drażnionym przez to, przeciwko czemu się występuje"25. Teoretyczka używa słowa snap także w odniesieniu do zerwania więzi międzyludzkich, dlatego tłumaczę je wymiennie na trzy sposoby, jako „załamanie nerwowe”, „pęknięcie” i „zerwanie”.

Załamanie nerwowe, choć inspirujące w myśleniu o żenującym kobiecym performansie, nie jest z nim tożsame. Może go natomiast poprzedzać albo być

23 Faith jest bohaterką powieści Fruit of the Lemon Andrei Levy - Sara Ahmed przywołuje tę książkę, żeby wyjaśnić swoje tezy.

S. Ahmed Snap! Feminist Moments, Feminist Movements, tekst zamieszczony jako część wpisu Snap! na blogu tejże, 21.05.2017, https://feministkilljoys.com/2017/05/21/snap/ (dostęp: 10.07.2019).

S. Ahmed Living a feminist life, Duke University Press, Durham 2016, ebook, lok. 3575. 
jego siłą napędową. Między pęknięciem a performansem zachodzą jednak wyraźne różnice. Przede wszystkim żenujący kobiecy performans nie zostaje wykonany spontanicznie, jest zaplanowany i przygotowany. Performerka nie tylko uwalnia swoje emocje, ale też szuka określonej formy dla ich wyrażenia. Sara Ahmed pisze tymczasem, że:

Załamanie nerwowe nie zawsze jednak jest świadomym aktem oporu. Nie zawsze jest też zaplanowane. Przeciwnie, może zniszczyć nawet najlepszy plan. W załamywaniu się może chodzić o intensywność doświadczanej sytuacji - kiedy jesteś proszona o zrobienie czegoś i czujesz, że ta prośba to tym razem już za wiele, nawet jeśli wcześniej ją spełniałaś. Coś może okazać się zbyt dużym obciążeniem, jeszcze zanim zdamy sobie z tego sprawę. Kiedy się załamujemy, nie zawsze mamy świadomość, co robimy albo co chcemy osiagnąć. A mimo to pękamy właśnie z powodu tego, co robimy. Załamujemy się, bo nie możemy dłużej być w miejscu, w którym jesteśmy. Być może załamanie nerwowe uwzględnia inny rodzaj optymizmu ${ }^{26}$, który możemy nazwać optymizmem bez przyszłości, takim, który robi przerwę, żeby zapoczątkować coś nowego, nie wiedząc, czym to nowe jest albo czym mogłoby być, optymizmem, który nie nadaje treści temu, co będzie. ${ }^{27}$

Punktem wspólnym załamania nerwowego i żenującego kobiecego performansu jest przekonanie, że dana sytuacja nie może trwać i trzeba ją natychmiast zmienić. Jak pisze Ahmed: „Przez załamanie nerwowe mówisz: nie będę reprodukować świata, którego nie mogę znieść, świata, o którym sądzę, że nikt nie powinien go znosić"

Żenujący performans wyraża to samo. Niekiedy podobne są też jego skutki, bo jak pisze Ahmed, moment pęknięcia może być zarzewiem rewolucji, która "często jest utożsamiana z tym, co wywołuje: z chaosem. Jeśli chaos zostaje wywołany, kiedy twoja wola nie chce się podporządkować woli innych, to niech tak będzie"29. Zgoda na wywołanie chaosu jest kolejnym punktem wspólnym między tymi dwoma zjawiskami. Podobnie jak to, że performerka,

Inny od okrutnego optymizmu, kategorii zaproponowanej przez Lauren Berlant w książce Cruel Optimism (Duke University Press Book, Durham 2011). 
która publicznie podnosi pewien problem, zaczyna być widziana jako źródło problemu. Pęknięcie jest jednak nagłe i niespodziewane, jego widowiskowe elementy (płacz, krzyk i tak dalej) są niejako skutkiem ubocznym przemiany, która dokonuje się w osobie przechodzącej załamanie. Kategoria Ahmed kładzie więc nacisk na proces psychiczny, którego jedynie następstwem może być rewolucja. Żenujący kobiecy performans z miejsca skupia się natomiast na przemianie (albo chociaż sprowokowaniu) otoczenia, nie performerki.

Mogłoby się wydawać, że jednostkowe wystąpienia zawsze są skazane na niepowodzenie, zwłaszcza kiedy wykonywane są z pozycji słabej. Słaba czy pozornie słaba pozycja nie oznacza jednak automatycznie produkowania słabego dyskursu. Większość opisywanych przeze mnie performansów kończy się w jakimś stopniu sukcesem, choć jest on często odległy od zamierzeń. Czasem wystąpienie przynosi realną polityczną zmianę - tak było na przykład w przypadku Alicji Tysiąc, której sądowe zwycięstwo spowodowało modyfikację polskiego prawa. W latach 8o. sformułowana została teoria tak zwanej masy krytycznej, zgodnie z którą, żeby mówić o realnym politycznym wpływie, przedstawiciele danej grupy (najczęściej tej teorii używano do opisywania zaangażowania kobiet w politykę) muszą osiągnąć trzydziestoprocentową reprezentację. Teoria masy krytycznej zrobiła ogromną karierę i często była wykorzystywana przez aktywistki feministyczne do walki o zwiększenie kobiecej obecności w parlamencie ${ }^{30}$. W Polsce powołała się na nią na przykład Małgorzata Fuszara, występując w Sejmie w imieniu Kongresu Kobiet jako sprawozdawczyni obywatelskiego projektu ustawy o parytetach ${ }^{31}$. Jednak pojęcie masy krytycznej powstało w oparciu o błędne odczytanie tekstów dwóch badaczek, którym przypisywano autorstwo teorii - Rosabeth Moss Kanter i Drude Dahlerup. Jak tłumaczą Sarah Childs i Mona Lena Krook w artykule Should Feminists Give Up on Critical Mass? A Contingent Yes, zwłaszcza Drude Dahlerup od początku kwestionowała przekonanie o konieczności ilościowego zwiększenia kobiecej reprezentacji. Childs i Krook przywołują liczne badania, które pokazują, że kiedy więcej kobiet obejmuje polityczne urzędy, powstają różne możliwe scenariusze, także takie, w których prowadzi to do uchwalenia reakcyjnego prawa (bo mężczyźni czują się

30 Znaczenie opowieści o teorii masy krytycznej analizuje rzekoma współtwórczyni tej teorii Drude Dahlerup; por. tejże The Story of the Theory of Critical Mass, „Politics \& Gender" 2006 no. 2.

31 Por. Prof. Małgorzata Fuszara o parytetach, wystąpienie parlamentarne, "Gazeta Wyborcza", 18.02.2010, http://wyborcza.pl/1,76842,7578650,Prof__Malgorzata_Fuszara_o_parytetach. html (dostęp: 15.07.2019). 
zagrożeni i starają się w ten sposób przeciwdziałać zwiększaniu kobiecej władzy). Badaczki korzystają też z analiz, które wyjaśniają, że dwie grupy identycznie skonstruowane pod względem reprezentacji genderowej mogą zachowywać się odmiennie w zależności od tego, czy ich przedstawiciele są raczej „radykałami” (działaja, nawet kiedy inni nie działają), czy „,konserwatystami" (nie działają, dopóki wielu innych nie podejmie działań) ${ }^{32}$. Na tej podstawie Childs i Krook stawiają tezę, że często ważniejsza od ilościowej jest jakościowa reprezentacja polityczna i proponują przejście od teorii masy krytycznej do teorii krytycznych aktorów: „Krytyczni aktorzy to ci, którzy samodzielnie inicjują propozycje polityczne, nawet kiedy kobiety stanowią mniejszość, i zachęcają innych do podejmowania kroków w celu promowania polityki wobec kobiet niezależnie od procentowej reprezentacji"33.

Childs i Krook pokazują, że zdeterminowany i odważny podmiot jest w stanie w pojedynkę, albo zachęcając innych do działania, doprowadzić do dużej zmiany (oczywiście działa to też w drugą stronę: odpowiednio aktywny podmiot może nakłonić do działań reakcyjnych). Nie oznacza to, że badaczki są skłonne całkowicie porzucić teorię masy krytycznej, zauważają bowiem, że powoływanie się na nią pozwoliło na realne zwiększenie kobiecej aktywności oraz że do przeprowadzenia zmian na dużą skalę nie wystarczy kilka znaczących indywidualności.

Żenujące performerki aspirują do roli krytycznych aktorek - starają się samodzielnie zainicjować zmiany i podejmują działania zwłaszcza wtedy, kiedy inni pozostają bierni. Mogą przy tym chcieć inspirować działania zbiorowe albo (jak Joanna Szczepkowska) czerpać przyjemność z działania na przekór wszystkim.

\section{Po czwarte: żenujący kobiecy performans jest przeciwieństwem szaleństwa}

W cytowanym wcześniej fragmencie Ahmed podkreśla, że załamanie, w przeciwieństwie do żenującego kobiecego performansu, nie zawsze jest świadome i kontrolowane. Badaczka stara się wydobyć związek między utratą panowania nad sobą a załamaniem nerwowym, ironicznie nazywając je „kobiecą chorobą"34. Zdaje się jednak, że jest odległa od utożsamiania go

Por. S. Childs, M.L. Krook Should Feminists Give Up on Critical Mass? A Contingent Yes, „Politics \& Gender" 2006 no. 2, S. 527. 
z niepoczytalnością. Żenujący kobiecy performans także nigdy nie wkracza w obszar szaleństwa jako stanu chorobowego, choć jego wykonawczynie często są obraźliwie określane mianem wariatek, a media i internauci debatują nad ich stanem emocjonalnym i zdrowiem psychicznym.

Stanowcze podkreślenie, że żenujący kobiecy performans to przeciwieństwo szaleństwa, jest istotne, ponieważ w badaniach feministycznych istnieje tradycja interpretowania kobiecej niepoczytalności jako aktu rebelii, często jedynej, na jaką kobiety mogą sobie pozwolić w opresyjnej, patriarchalnej rzeczywistości. Żenujące performerki ze względu na opinie wyrażane niekiedy przez adresatów ich działań (oraz ze względu na naruszanie obyczajów, etykiety i dobrych manier) mogłyby zostać uznane za kontynuatorki tradycji histeryczek i innych szalonych kobiet. Jak jednak udowodniła Marta Caminero-Santangelo, dopatrywanie się w szaleństwie formy emancypacji jest błędne. W książce Mad Woman Can't Speek: Or why Insanity is Not Subversive Caminero-Santangelo tłumaczy, że:

Być może powodem, dla którego figura szalonej kobiety ciągle jest tak ponętna, jest to, że oferuje ona iluzję władzy, chociaż w rzeczywistości zapewnia jedynie symboliczne rozwiązanie skutkujące umocnieniem bezsilności. Punktem wyjścia dla moich rozważań jest założenie, że poszukiwanie subwersywnego potencjału w literackiej figurze szalonej kobiety to nie tylko gest implikujący silne represje [...] ale przede wszystkim fundamentalny błąd, bo symboliczne rozwiązania wynikające z rozumienia szalonej kobiety jako przeciwstawiającej się patriarchatowi finalnie wpychają kobiety w pułapkę milczenia. [...] Szaleństwo jest nieodłącznie związane z tym, co Teresa de Lauretis określa jako „technologie genderu" i co zapewnia iluzję władzy, podczas gdy w rzeczywistości sytuuje szalony (nie)podmiot poza jakąkolwiek sferą, w której władza może być sprawowana. ${ }^{35}$

Zdaniem badaczki szaleństwo jest wysoce nieskuteczne w zapewnianiu emancypacji, ponieważ jest równoznaczne z poddaniem się dominującym dyskursom. Szalona kobieta nie jest zdolna do „tworzenia znaczeń, a więc do produkowania reprezentacji uznawanych w społeczeństwie za znaczące"36,

M. Caminero-Santangelo Mad Woman Can't Speek: Or why Inanity is Not Subversive, Cornell University Press, Ithaca-Londyn 1998, s. 4. 
to inni działają w jej imieniu, decydują o jej ciele i tłumaczą jej zachowania. Właśnie na tym polega opisane przez Caminero-Santangelo usytuowanie poza sferą, w której sprawowana jest władza. Oznacza to, że szalona kobieta pozbawiona jest jakiejkolwiek politycznej sprawczości. Tymczasem skuteczna emancypacja musi być przeprowadzona narzędziami politycznymi i jest nie tyle usytuowaniem siebie poza sferą publiczną, ile działaniem w jej obszarze na rzecz zmiany panujących reguł gry. Elaine Showalter pisała:

Nawet szalonej kobiecie zdolnej do morderstwa nie udaje się uciec przed męską dominacją. Ucieka tylko przed jedną, niemożliwą do zniesienia powinnością kobiety przez przyjęcie wyidealizowanej, poetyckiej formy czystej kobiecości, którą stworzyła męska kultura: absolutnie irracjonalną, absolutnie emocjonalną oraz, kiedy już wypełni jedyne zadanie, do którego jest zdolna, absolutnie bierną. ${ }^{37}$

Odcięcie się od racjonalnego dyskursu i produkowania znaczeń oznacza niezdolność do komunikowania się także z innymi kobietami, tworzenia więzi, skazuje tym samym na totalną samotność.

Żenujący performans nigdy nie rezygnuje z tworzenia znaczeń. Wręcz przeciwnie, dzięki rozpoznaniu zasad działania dyskursu, któremu się przeciwstawia, potrafi bardzo trafnie je demaskować, negować i wyśmiewać, ale także przekształcać na swój użytek. Szalona kobieta jest pozbawiona głosu, przez co zostaje zlekceważona, natomiast żenująca performerka może irytować, ale jej wystąpienie wywołuje spór, polemikę, prowokuje do komentarzy i odpowiedzi. W ten sposób za sprawą żenującego performansu głos jego wykonawczyni, który w innych warunkach mógłby nie zostać usłyszany, staje się centrum dyskusji. Żenująca performerka zawsze bierze w niej czynny udział. I nigdy nie zostaje sama - jej działania gromadzą nie tylko krytyków, ale także zwolenników, a nawet naśladowców.

\section{Po piąte: żenujący kobiecy performans jest widowiskowy}

Erwing Goffman w artykule Zażenowanie a organizacja społeczna uznaje zażenowanie za powszechne, choć bardzo mocne doświadczenie, któremu podlegają ludzie, wchodząc w relacje społeczne. Zakres sytuacji, w których

37 E. Showalter The Female Malady: Women, Madness and English Culture, Time Warner Books, New York 1985 , s. 17. 
podmiot jest zażenowany i które rozważa badacz, jest bardzo wąski (dużo węższy niż w tekście Luke'a Purshouse'a). To pozwala mu na stwierdzenie, że zmieszanie powstaje wtedy, kiedy oczekiwania i wyobrażenia podmiotu na temat osoby, z którą wchodzi w interakcję, zostają zagrożone ${ }^{\mathbf{3 8}}$. Dzieje się tak, kiedy w żenującym performansie wykonawczyni wykonuje gest, którego nikt się nie spodziewa. Goffman nie dopuszcza oczywiście możliwości, w której zażenowanie zostaje wywołane celowo - w jego myśleniu afekt ten jest zawsze tylko błędem w komunikacji. Jego zdaniem wyrozumiałość, takt i zdolności interpersonalne to podstawowe umiejętności, które pozwalają na uniknięcie wprawiania innych w zakłopotanie. Są to jednocześnie umiejętności (pokrewne do etykiety Purshouse'a czy manier Fraser) często identyfikowane przez badaczki feministyczne jako te, których nabycie przez dziewczynki w procesie wychowania staje się dla nich najbardziej blokujące. Jeśli zażenowanie pojawia się, kiedy wyobrażenia jednej osoby na temat drugiej zostają zagrożone, możemy się domyślać, że takt i wyrozumiałość przybierają często postać spełniania oczekiwań innych, nawet jeśli stoją one w sprzeczności z oczekiwaniami taktownego podmiotu. Carol Gilligan w książkach Innym gtosem. Teoria psychologiczna a rozwój kobiet oraz Chodźcie z nami! Psychologia i opór pokazywała, jak w procesie socjalizacji dziewczynki przyswajają sobie przekonanie, że aby podtrzymać pozytywne relacje z innymi ludźmi, muszą stłumić swój wewnętrzny głos ${ }^{39}$. Jak pamiętamy, Sara Ahmed podobnie przedstawia kobiety, które pękają - do pewnego momentu spełniają oczekiwania otoczenia, aż wreszcie załamują się i zaczynają dążyć do zmiany. Siła żenującego kobiecego performansu polega na świadomym zerwaniu z zasadą taktu. To pozwala jednak zrozumieć skalę ryzyka, które podejmuje wykonawczyni, zwłaszcza jeśli jest osobą publiczną, utrzymującą się z konsumowanej przez odbiorców produkcji artystycznej albo wykonuje zawód polegający na zdobywaniu przychylności wyborców.

Celowe wywoływanie zażenowania może być jednak skuteczne. Zdaniem Goffmana zażenowanie ma potężny wpływ na osoby, które go doświadczają - działa bowiem demaskująco, dezorientująco i dezorganizująco:

38 Por. E. Goffman Zażenowanie a organizacja społeczna, przeł. A. Bukowski, w: Socjologia. Lektury, red. P. Sztompka i M. Kucia, Znak, Kraków 2005.

39 Por. C. Gilligan Innym głosem. Teoria psychologiczna a rozwój kobiet, przeł. B. Szelewa, Wydawnictwo Krytyki Politycznej, Warszawa 2015; tejże Chodźcie z nami! Psychologia i opór, przeł. S. Kowalski, Wydawnictwo Krytyki Politycznej, Warszawa 2013. 
Wydaje się, że kluczowym momentem interakcji jest chwila, kiedy jednostka rezygnuje z dalszego ukrywania zmieszania i odgrywania pewności siebie: uderza w płacz albo wybucha paroksyzmami śmiechu, wpada w złość, dostaje szału, mdleje, rzuca się do najbliższego wyjścia albo zamiera w bezruchu, kiedy ogarnia ją panika. Po czymś takim niezwykle trudno wrócić jednostce do stanu równowagi. Musi bowiem odnieść się do interakcji owym głębokim, emocjonalnym doświadczeniem, co czyni prawie niemożliwym wywołanie wrażenia, że jak gdyby nigdy nic jest z innymi w interakcji. [...] Moment kryzysu jest oczywiście zdeterminowany społecznie: przełom w zachowaniu jednostki odsyła nas do podzielanych w całej grupie standardów poprawnego zachowania. Dość rzadko, ale zdarza się tak, że podobnego przełomu doświadczają wszyscy uczestnicy spotkania, a potem nie potrafią już stworzyć nawet pozorów poprawnej interakcji. Maleńki system społeczny zbudowany podczas interakcji ulega dezintegracji, uczestnicy albo się rozchodzą, albo usiłują naprędce przyjąć nowe role. ${ }^{40}$

Choć Goffman nie dostrzega tego potencjału, jego myślenie wskazuje, że umiejętnie zastosowana gra żenadą może zniszczyć istniejące struktury społeczne lub dyskursywne. Szczególnie że, jak dodaje badacz:

Tracąc ustalony i legitymizowany obiekt, wobec którego mogli do tej pory budować i odgrywać spoistość własnych wizerunków, wszyscy inni [tj. świadkowie żenującej sytuacji, którzy nie biorą czynnie udziału w interakcji] znajdują się w sytuacji niedopowiedzianej i niezręcznej. To dlatego zażenowanie wydaje się zaraźliwe i ma tendencję do rozprzestrzeniania się. Jeśli już się zdarzyło, obejmuje poczuciem zażenowania coraz szersze kręgi. ${ }^{41}$

W przypadku żenującego kobiecego performansu rozprzestrzenianie się zażenowania jest dodatkowo ułatwione i wzmożone, bo wystąpienie ma charakter publiczny i bardzo szyblko staje się tematem medialnym. Wszystkie żenujące performerki korzystają z siły, jaką zapewnia im rozgłos, potrafią grać z nowymi mediami i używać ich do wirusowania przestrzeni komunikacji. 


\section{***}

Nazwa „żenujący kobiecy performans" opisuje zatem podstawowe czynniki, które konstytuują zdarzenie: zażenowanie oznacza podstawowy afekt, który zostaje rozegrany; kobiecość to pozycja, z której wykonawczyni zabiera głos; słowo "performans" sugeruje zarówno widowiskowość, jak i sprawczość (w tym przypadku w obrębie sfery publicznej). Oczywiście obraz zarysowany powyżej znacznie się komplikuje, kiedy przystępujemy do analizy poszczególnych żenujących performansów. Fala krytyki (medialnej i społecznej), pouczeń, nienawiści i pogardy, która spada na performerki, jest często tak przytłaczająca, że utrudnia dostrzeżenie emancypacyjnego potencjału wykonanego gestu. Zdarza się także, że sam żenujący performans jest bardzo problematyczny, bo na przykład rezonuje z konserwatywnymi dyskursami. Tak było chociażby w przypadku Joanny Szczepkowskiej, która na portalu e-teatr.pl opublikowała felieton Homo dzieciństwo i uruchomiła homofobiczną dyskusję na temat istnienia rzekomego lobby homoseksualnego w polskim środowisku teatralnym ${ }^{42}$. Często też zmiany, jakie przynosi żenujący performans, są długofalowe, rozproszone, zamaskowane, a przez to bardzo trudne do uchwycenia. Kiedy jednak dostrzegamy potencjał w tego typu ryzykownych, problematycznych wystąpieniach, otwiera się przed nami perspektywa zrobienia użytku ze słabej pozycji, w której kobiety od stuleci umieszcza patriarchat. 


\section{Abstract}

\section{Katarzyna Waligóra}

JAGIELLONIAN UNIVERSITY (CRACOW)

An Underrated Emancipatory Strategy: The Embarrassing Female Performance

Waligóra defines the embarrassing female performance as an emancipatory gesture performed in the public sphere to disturb broadly accepted norms and conventions. This type of performance provokes consternation, aversion and aggression, but it can also be an effective tool to shift the discourse or general views on a given subject, and it can even lead to a change in legislation. Drawing on feminist theory (e.g. Sara Ahmed, Elaine Showalter, Marta Caminero-Santangelo), the theory of affect (Martha Nussbaum) and sociology (Erving Goffman, Nancy Fraser) Waligóra presents five basic traits of this type of performance.

\section{Keywords}

embarrassment, shame, feminism, public sphere, performance, shock 